\title{
Development of Gas Sensing Technique Using Narrow-Linewidth Terahertz-Wave Source
}

\author{
Yuji Takashima Non-member (Nagoya University) \\ Koji Suizu Non-member (Nagoya University) \\ Takayuki Shibuya Non-member (RIKEN) \\ Chiko Otani Member (RIKEN) \\ Kodo Kawase Member (RIKEN)
}

Keywords : terahertz wave, gas spectroscopy, remote sensing

The terahertz-wave (THz-wave) electromagnetic region is attractive because it has the potential for adoption to remote harmful-gas sensing applications in disaster environments. Infrared and visible waves, for example, cannot be adopted in this situation because aerosols prevent propagation of the waves to the target. In this study, we developed a tunable narrow-linewidth THz-wave source for this purpose. The THz-wave source must have a linewidth under $1 \mathrm{GHz}$ because the linewidth of $\mathrm{CO}$ gas, one of the harmful gases present at fire disasters, is about $4 \mathrm{GHz}$. One of the candidate systems that satisfies this requirement is an injection-seeded THz-wave parametric generator (is-TPG). An is-TPG has a very narrow linewidth, about $100 \mathrm{MHz}$, and high peak power; thus, it would be a superior gas-sensing system. An air window exists in the 0.5 - to $1.0-\mathrm{THz}$ region that permits about $50 \mathrm{~m}$ of long-range propagation. The system should have enough power and tunability in the wave region under $1 \mathrm{THz}$.

A schematic of the is-TPG system is shown in Figure 1. We have used the is-TPG mainly in the 1-3 THz region. The conventional is-TPG system has a slightly lower output power in the wave region under $1 \mathrm{THz}$. We optimized the is-TPG system for low frequency generation through accurate alignment of the seeder beam path, successfully suppressing the reduction of output power in the low-frequency region, as shown in Figure 2.

An important consideration of remote gas sensing at fire disasters is the detection of $\mathrm{THz}$ waves that contain gas absorption information and are reflected by building materials. Thus, we

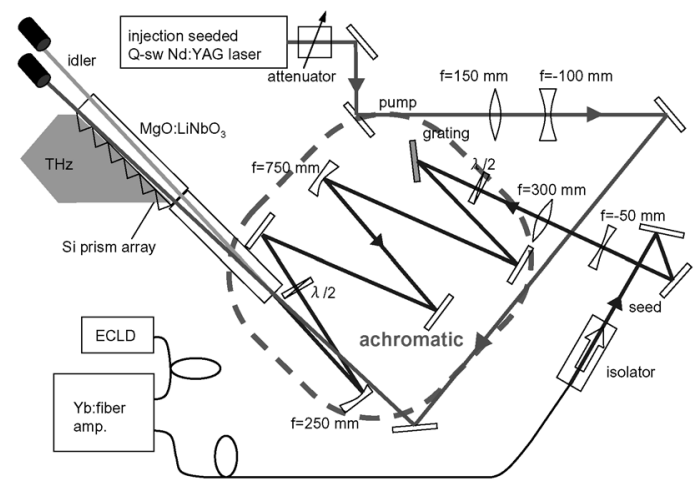

Fig. 1. Experimental setup for is-TPG

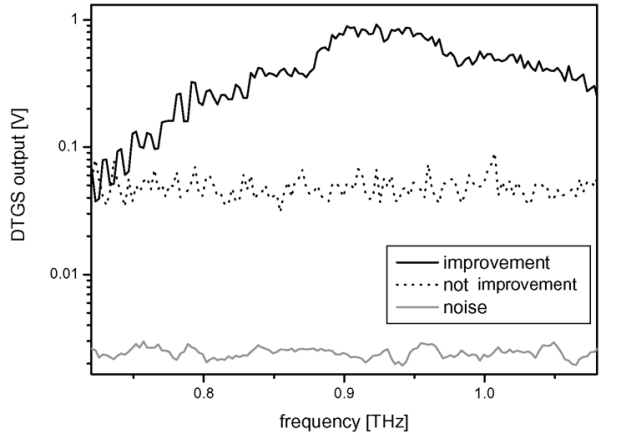

Fig. 2. THz-wave spectrum in the low frequency region

demonstrated absorption spectroscopy of $\mathrm{N}_{2} \mathrm{O}$ gas using $\mathrm{THz}$ waves reflected off building material. We used harmless $\mathrm{N}_{2} \mathrm{O}$ gas as the target, instead of dangerous $\mathrm{CO}$ gas, because $\mathrm{N}_{2} \mathrm{O}$ gas has an absorption line spectrum similar to that of $\mathrm{CO}$ gas. The generated THz-wave propagated through a gas cell filled with $\mathrm{N}_{2} \mathrm{O}$ gas, reflected off a metal siding panel, re-propagated through the gas cell, and was detected by the Si-bolometer. As shown in Figure 3, absorption lines of $\mathrm{N}_{2} \mathrm{O}$ gas at 1.004 and $1.030 \mathrm{THz}$ were successfully detected. The observed linewidth and absorption frequencies agreed well with calculated values from the HITRAN simulator. We successfully demonstrated remote gas

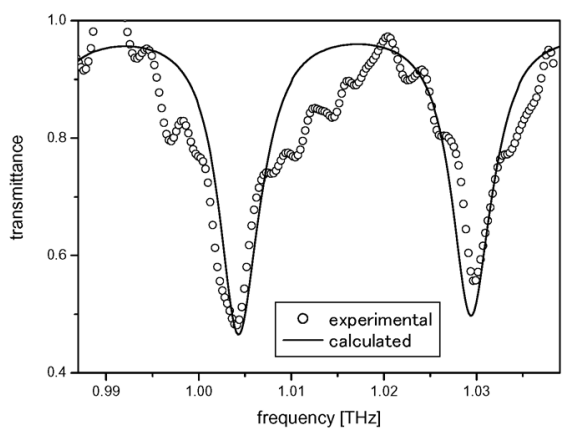

Fig. 3. Absorption spectrum of $\mathrm{N}_{2} \mathrm{O}$ gas generated by reflection off building material sensing in the model case of a fire disaster. 


\title{
狭線幅テラヘルツ波光源によるガスセンシング技術の開発

$\begin{array}{lll}\text { 非会員 高島 祐二* } & \text { 非会員 水津 } & \text { 光司* } \\ \text { 非会員 涉谷 孝幸 } * * * & \text { 正 員 大谷 知行** } \\ \text { 正員 川瀬 } & \text { 晃道 } * * *\end{array}$

論 文

Development of Gas Sensing Technique Using Narrow-Linewidth Terahertz-Wave Source.

Yuji Takashima*, Non-member, Koji Suizu*, Non-member, Takayuki Shibuya*,**, Non-member, Chiko Otani**, Member, Kodo Kawase*,**, Member

\begin{abstract}
A gas sensing technique on a fire site was developed. An output of is-TPG in a necessary low frequency for gas sensing controlled was obtained by optimizing the seeder so far. A reflection spectrum of an architectural material that used $\mathrm{N}_{2} \mathrm{O}$ gas that was the model gas of $\mathrm{CO}$ gas generated at a fire was successfully obtained, and a realizability of remote spectrum sensing in the $\mathrm{THz}$ range was showed experimentally. An attenuation rate of the THz-wave when the long distance was propagated under the atmospheric pressure was measured experimentally, and an error margin with the calculation was within $10 \%$. A calculation result was able to endure practical use in the THz range to which the accuracy of the calculation was doubted.
\end{abstract}

キーワード : テラヘルツ波, ガス分光, リモートセンシング

Keywords : terahertz wave, gas spectroscopy, remote sensing

\section{1. まえがき}

これまでテラヘルツ（THz）波は発生，検出共に困難であ ったが, 近年, レーザー光の波長変換を用いて比較的簡便 に $\mathrm{THz}$ 波発生が実現できるようになってきた。最も一般的 な方法は, 電気光学結晶や光伝導性アンテナ, 半導体, 超伝 導体等をフェムト秒レーザーで励起して広帯域な $\mathrm{THz}$ 波パル スを発生・検出する THz 波時間領域分光法 (THz-TDS) (1) (4) である。この THz-TDS は, 従来の熱型光源を用いた遠赤外 フーリエ変換分光光度計（FT-IR）に比べて, 非常に感度が 高く, 物質の $\mathrm{THz}$ 波分光やイメージング等に応用され, 成 果を上げている。

一方で, 物質の特定量子状態への励起, 超高分解能の分 光, 超高速光エレクトロニクス等への応用には, スペクト ル線幅の狭い周波数可変 $\mathrm{THz}$ 波光源が必要である。現在, 周波数 $1 \mathrm{THz}$ 程度以下の領域では, 比較的コンパクトで発 振スペクトル幅の狭い周波数可変な光源である後進波管 （BWO）が利用できるが, 寿命が数百時間程度と短く, BWO

\footnotetext{
* 名古屋大学

干464-8603 名古屋市千種区不老町

Nagoya University,

Furo-cho, Chikusa-ku, Nagoya 464-8603

** 理化学研究所

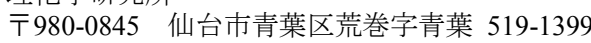
RIKEN,

519-1399 Aramaki-Aoba, Aoba-ku, Sendai 980-0845
}

の出力が急減する $1 \mathrm{THz}$ 以上の高周波領域での光源開発は 遅れている。

この領域における広帯域周波数可変 $\mathrm{THz}$ 波光源を以下に 挙げる。

( i ) 自由電子レーザー ${ }^{(5)}$ は, 相対論的電子ビームを周期 磁場中で蛇行運動させてレーザー発振する方式で, 原理的 に任意の波長の $\mathrm{THz}$ 波の発生が可能である。しかし, 大型 装置であるため研究用途にほぼ限られると考えられる。

(ii ) p-Ge レーザー(6)は, 強磁場中で正孔の円運動を起こ し反転分布を形成してレーザー発振する方式の広帯域波長 可変 $\mathrm{THz}$ 波光源であり, テーブルトップ化も進められてい る。液体へリウムを要するため研究用途寄りの光源とも考 えられる。

(iii) 非線形光学効果を用いた $\mathrm{THz}$ 波パラメトリック光 源は, 後述するとおり常温動作かつテーブルトップサイズ の広帯域波長可変光源であり, 研究及び産業用途が見込ま れる。

(iv) 以上に挙げた( i )〜 (iii)の方式はパルス出力である のに対して, 2 台の半導体レーザー光を低温成長 GaAs 製の フォトミキサー上で光混合する方式 ${ }^{(7)}$ は, 連続波出力かつテ ーブルトップサイズの広帯域波長可変光源であり, 高出力 化が進むと研究及び産業用途に魅力的である。

また, 中赤外域で高出力を実現している量子カスケード レーザー ${ }^{(8)}$ も, 原理的に波長可変性に乏しく, $3 \mathrm{THz}$ 以下の 
領域では，数例の報告例はあるものの，現在はレーザー発 振が困難である。このため, 可搬性にも通じるコンパクト で室温動作かつ簡便な $\mathrm{THz}$ 波光源が実現すれば, $\mathrm{THz}$ 波領 域の研究が飛躍的に進展するのは間違いない。

$\mathrm{THz}$ 波の大きな特徴は, マイクロ波帯や準ミリ波帯（1 $\mathrm{GHz} \sim 30 \mathrm{GHz}$ ) 電波に比へ，一桁以上の高周波数（短波長） であるため高空間分解能性を有すること, 赤外線や可視光 に比べると波長が長いため伝搬において塵, 煙, 炎などに よる散乱が少ないこと, $\mathrm{THz}$ 波帯に存在する物質固有の吸 収スペクトルによって有毒ガス，危険物質を検知できるこ となどである。

そこで，この $\mathrm{THz}$ 波の特徵を，大規模地震などの災害発 生時におけるセンシングに活用寸れば，従来技術（X 線， 赤外線，マイクロ波，ミリ波）では困難であった新しい情 報収集が可能となり, さらに得られた情報の迅速な流通と 利用によって, 被災者救援や二次災害防止などに役立て, 災害被害を最小限に抑えることに貢献できると考えられ る。

本論文では非線形光学効果 ${ }^{(9)(10)}$ を用いたパラメトリック 波長変換による $\mathrm{THz}$ 波光源, 中でも, 光注入型 $\mathrm{THz}$ 波パラ メトリック発生器 (injection-seeded Terahertz-wave Parametric Generator : is-TPG) の構築を行う。本光源は, 非線形光学結 晶と励起光源だけで $\mathrm{THz}$ 波を発生させるため, 小型簡便か つ室温動作可能であり, $\mathrm{LiNbO}_{3}$ 結晶のパラメトリック利得 の広帯域性から, 周波数領域も $1 \mathrm{THz}$ 以下から $3 \mathrm{THz}$ 以上 と広い。さらに, 発振スペクトル線幅も約 $100 \mathrm{MHz}$ 程度ま で狭線化が可能であり ${ }^{(11)}$, 高分解能の分光に有効である。 特に, 遠隔ガスセンシングで必要となる $1 \mathrm{THz}$ 以下の低周 波発生を目的とし，従来光源の改良を行う。

さらに，開発した本光源を用い，大規模地震時などにお ける被災建物において, 煙霧や火災などが視界の障害とな っているような状況下で, 火災時に発生する一酸化炭素な どの有毒ガスを，THz 波を用いた分光的手法により効果的 に検出し物質材料データベースなどの $\mathrm{THz}$ 帯固有の情報を 用いて処理することによって，災害時の救援や二次災害防 止などに効果的に役立てることを可能にする, 遠隔センシ ング技術の実現可能性を示す。

\section{2. $\mathrm{THz}$ 帯ガスセンシングの検討}

災害現場での有毒ガス同定のためには，そのガス固有の 吸収線を含み, 大気中水蒸気の吸収が弱く, かつ建材等の 災害現場での混在物質の吸収線の存在しない周波数帯での 検出が重要である。この目的に適した $0.5 \sim 1 \mathrm{THz}$ 帯で, 検 討を行う。

ガスセンシングの実験を行うにあたり，初期検討として， 実際の使用状況を想定した, COの透過スペクトル等をシミ ュレーションする必要がある。シミュレーターには, HITRAN を使用し, 大気とCO についての透過スペクトルを 計算した。尚, この領域での吸収は, 分子の回転モードに 起因するものである。

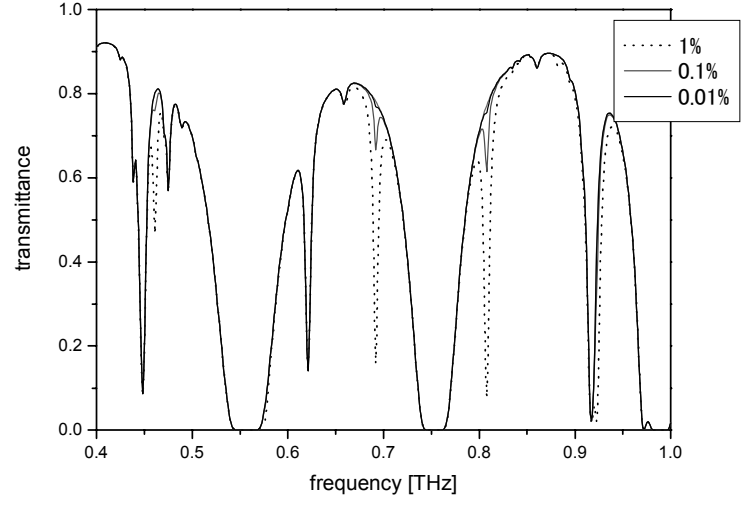

Fig. 1. Absorption spectrum change according to density of CO.

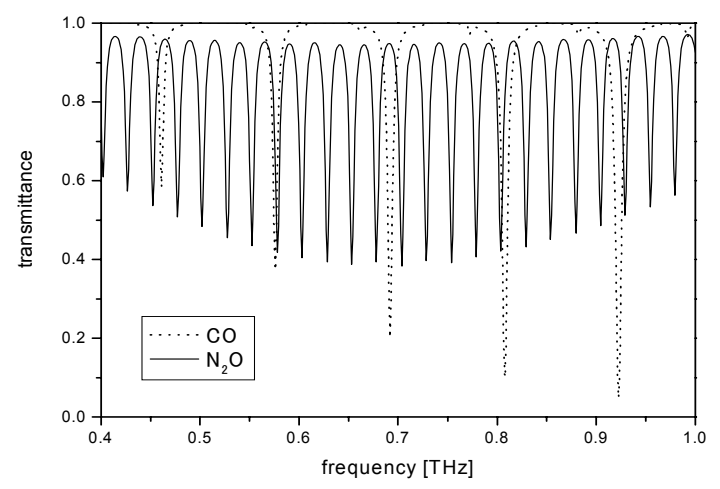

Fig. 2. Absorption spectrum of $\mathrm{N}_{2} \mathrm{O}$.

Fig. 1 に 1 気圧, 湿度 $40 \%$ の大気の透過スペクトルと CO の大気混入濃度による透過スペクトル変化を示す。空気層 として, 大気圧, $23^{\circ} \mathrm{C}, 25 \mathrm{~m}$ 往復して得た透過スペクトル に対し, $\mathrm{CO}$ 層として, 大気圧の空気中に $\mathrm{CO}$ の濃度が 0.01 〜 \%になるように CO 分圧をコントロールし, $23^{\circ} \mathrm{C}, 5 \mathrm{~m}$ を往復して得たスペクトルを加算した。即ち, 全光路長 $60 \mathrm{~m}$ の大気に対し, $10 \mathrm{~m}$ の限定された区閒において当該濃度の $\mathrm{CO}$ が混在した状況を模擬的に再現したものである。尚, 大 気の吸収は，ほとんどが水蒸気による吸収である。0.63〜 $0.73 \mathrm{THz}$ 帯及び $0.8 \sim 0.9 \mathrm{THz}$ 帯に大気の空が存在すること が分かった。大気中においてガス分光を行う際には, 大気 による減衰の影響が少ない大気空の周波数領域を用いる必 要がある。また，CO ガス吸収による透過率の変化は，0.1\% の濃度 (人が吸気すれば死亡に至る危険性) であれば， $15 \%$ 程度, $0.01 \%$ の濃度（吸気により昏睡状態に陥る可能性）の 場合に $1.5 \%$ であるこんら, 十分に検出可能であると言え る。また, $\mathrm{CO}$ 濃度 $0.15 \%$ で致死量であれば, 致死量程度も しくはそれ以下の濃度で検出が可能ということになる。

実際にCO ガスを用いて検出実験を行うのは, 非常に危険 であるため, 比較的安全なテストサンプルを用いる必要が ある。この領域で顕著な吸収のあるガスを調べた結果, 亜 酸化窒素 $\left(\mathrm{N}_{2} \mathrm{O}\right)$ ガスに吸収線が存在することが分かった (Fig. 2)。尚, 本計算では光路長 $50 \mathrm{~cm}$, 各ガスの分圧を 0.5 気圧とした。吸収線幅も $\mathrm{CO}$ と同程度で連続した吸収線を持 
つこと，化学的に安定であるために分解などによってガス セル内での濃度変化が無いことから, CO のモデルガスとし て用いることとした。

また，非常に重要な項目として，センシングに用いる周 波数帯の大気空の実際の減衰率を実験的に求める必要があ る。現行用いられている数值解析シミュレーターでは, 水 蒸気の圧力広がり係数に正確な值を使用していないため, 実際に長距離伝播させた場合, 減衰率の実験值と計算值と で結果が大きく異なる可能性が高い。仮に圧力広がり係数 をかなり正確に求めたとしても, 大気空は複数の吸収線の 合間にあるため, 係数のわずかな差が大気空の減衰率に大 きく影響を及ぼしてしまう領域であり，このような方法で の大気空減衰率の見積もりには原理的に限界があると言え る。一番正確で確実な方法は, 実際にテラヘルツ波の長距 離伝播を行い, 真空状態と大気状態との差を実験的に確認 することである。

\section{3. $\mathrm{THz}$ 波パラメトリック発生の原理 ${ }^{(9)(12),(13)}$}

Q スイッチ動作パルスレーザーから発生したレーザー光 のような強電場を持つ電磁波が横光学フォノンモードをも つ非線形光学結晶を通過すると, 光子と格子振動が結合し てポラリトンと呼ばれる素励起状態を形成する。 $\mathrm{THz}$ 波は ポラリトンを介した誘導ポラリトン散乱によって発生す る。このようにして, ポンプ光, アイドラー光, ポラリト ン（THz 波）の間に強い相互作用が発生する。Fig. 3 のよう に, ポラリトンは共鳴周波数付近では格子様に振舞うが, 共鳴周波数から十分離れた低周波数領域では光子様に振舞 う。誘導ポラリトン散乱過程では, ポンプ光 $\left(\omega_{p}\right)$ とアイ ドラー光 $\left(\omega_{i}\right), \mathrm{THz}$ 波 $\left(\omega_{s}\right)$ の間に, エネルギー保存則

$$
\omega_{p}=\omega_{i}+\omega_{s}
$$

と運動量保存則（ノンコリニア位相整合条件）

$$
\boldsymbol{k}_{p}=\boldsymbol{k}_{i}+\boldsymbol{k}_{s}
$$

が成立し, 屈折率の波長分散特性のためにポンプ光の光軸 からの散乱角に応じてアイドラー光および $\mathrm{THz}$ 波の波長が 定まる。連続した広帯域波長可変性は, シード光の波長と 入射角を変化させることで得られる。TPG の帯域幅は，結 晶のパラメトリックゲインと $\mathrm{THz}$ 帯における吸収係数によ って決まる。

\section{4. is-TPG の特性}

位相整合角は結晶に入射するシード光の波長により異な るため, シード光の波長を変化させると同時に，シード光 が結晶一適切な角度で入射するように毎回調整する必要が ある。そこで, Fig. 4 に示すアクロマティック光学系により, ミラーを再調整することなしに，シード光を常に適切な位 相整合角で結晶に入射させることができる(14)。Fig. 5 に本研 究で構築した is-TPG の実験系を示す。アクロマティック光 学系では 2 枚のレンズを用いるが, 本研究では光源をコン

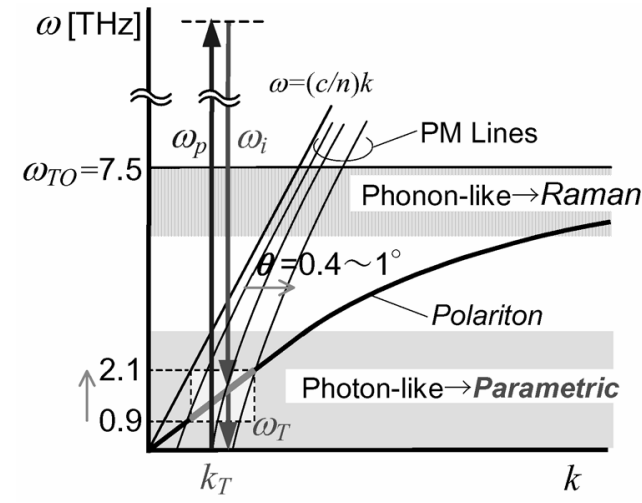

Fig. 3. Dispersion relation of the polariton.

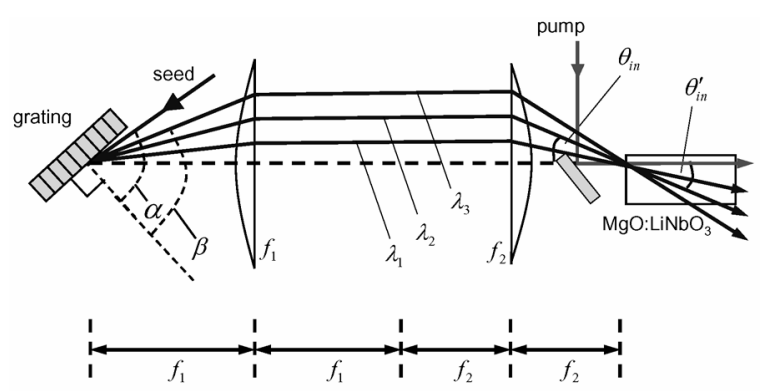

Fig. 4. Schematic of an achromatically is-TPG.

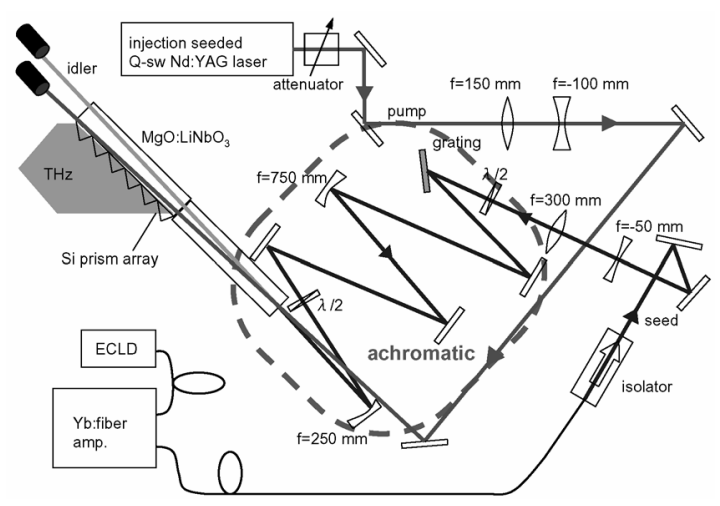

Fig. 5. Experimental setup for is-TPG.

パクトにするために, レンズの代わりに 2 枚の凹面鏡を用 いた。非線形光学結晶には $\mathrm{THz}$ 波の変換効率の良い $5 \mathrm{~mol} \%$ $\mathrm{MgO}: \mathrm{LiNbO}_{3}$ を使用し，2 個を縦列に配置している。これは, 結晶を縦に 1〜3 個並べた場合を比較して, 2 個のときに最 大の $\mathrm{THz}$ 波出力が得られたためである(11)。また, 使用した 結晶は $65 \times 4 \times 5 \mathrm{~mm}(x \times y \times z$-軸 $)$ のサイズに切り出し, 両 端面を平行研磨し $1064 \mathrm{~nm}$ 付近での無反射（AR）コーティ ングが施されている。また, 発生した $\mathrm{THz}$ 波は $\mathrm{LiNbO}_{3}$ 結晶 の屈折率（n〜6）の大きさ故に, 界面で全反射を起こし, 外部への取り出しが困難となる。そのため, 結晶に Si プリ ズムアレイ $(n \sim 3)$ を取り付け, $\mathrm{THz}$ 波の外部への取り出 し効率を向上させている(11)。

ポンプ光には波長 $1064 \mathrm{~nm}$, 繰り返し周波数 $10 \mathrm{~Hz}$, パル

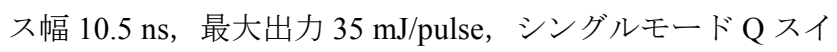


ッチ動作 Nd:YAG レーザーを用いた。また, 本実験で使用 した結晶は，THz 帯における吸収係数が $10 〜 100 \mathrm{~cm}^{-1}$ 程度 と大きい。発生した $\mathrm{THz}$ 波の結晶内部での吸収損失を最小 に抑えるためには, ポンプ光を後段の結晶の $y$ 面近傍に通過 させる必要がある。そのため, 後段の結晶を約 $1 \mathrm{~mm}$ 程度ず らし,さらにポンプ光のビーム径をテレスコープにより 0.76 $\mathrm{mm}$ 程度に絞り, 後段の結晶のできる限り $y$ 面近傍を通過さ せるようにポンプ光を結晶にほぼ垂直に入射した。

シード光は, 外部共振器型波長可変半導体レーザー (ECLD) を $\mathrm{Yb}$ ファイバ増幅器で増幅して用いた。いずれも 連続波 $(\mathrm{CW})$ かつシングルモードである。波長可变半導体 レーザーから出力された光は, ファイバを通ってファイバ 増幅器に入る。光は増幅された後, 戻り光を防ぐためエア パスアイソレーターを通り, フリースペースヘ出力される。 その後, テレスコープによりビーム径を $1.1 \mathrm{~mm}$ 程度に広げ ている。また，シード光は波長を変えても前段の結晶の端 面でポンプ光と交わるように，常に前段の結晶端面の同じ 位置を通過するように調整した。結晶入射直前でのシード 光パワーは $400 \mathrm{~mW}$ であり, 波長可変範囲は $1 \sim 3 \mathrm{THz}$ の範 囲を十分にカバーするものである。尚, ポンプ光, シード 光ともに, 波長板を使い偏光方向が結晶の $z$ 軸方向に平行に なるようにして，結晶に入射している。

$\mathrm{THz}$ 波の出力は, 焦電検出器 (DTGS 検出器) 及び, $\mathrm{Si}$ ボロメーターで測定した。また，THz 波エネルギー[J/pulse] と Si ボロメーター及びDTGS 出力 $[\mathrm{V}]$ の関係は換算式が存在 するが，正確であるとは言えないため，本論文では $\mathrm{THz}$ 波 出力を DTGS 出力[V]として表示する事とする。参考までに, Si ボロメーターの換算式として, 現状もっとも真值に近い と思われるものは $10 \mathrm{~V} \sim 110 \mathrm{pJ}$ であり, DTGS 検出器の感度 は Si ボロメーターのそれに比べて 1/20〜1/100 程度であり, 個体差が大きい点に留意が必要である。また, is-TPG から 出射した $\mathrm{THz}$ 波は縦方向に $4^{\circ}$ 程度で広がっているため, シリンドリカルレンズで平行にしたのち, 凸レンズで集光 して検出器で検出した。

ポンプ光パワー密度 $370 \mathrm{MW} / \mathrm{cm}^{2}$, シード光パワー400 $\mathrm{mW}$ における, 発生した THz 波のスペクトルを Fig. 6 に示 す。シード光は, 最も出力の見込める $1.5 \mathrm{THz}$ 付近で位相整 合角が合うように調整した。横軸はポンプ光とシード光の 波長差から算出した物であるが, メタルメッシュによるス キャニングファブリペローエタロンによる波長の実測值と 良い一致を示していた。尚, 図中の $1.70 \mathrm{THz}$ 及び $1.75 \mathrm{THz}$ 付近の吸収は水蒸気による吸収である。1.5 THz 付近におい て, THz 波出力が DTGS の検出上限に達していることが分 かる。1 THz 以下の低周波域において $\mathrm{THz}$ 波の出力が弱く なった原因としては, 所望の波長帯においてシード光が正 確な位相整合角で結晶に入射していないことが考えられ る。低周波側では, 位相整合角がかなり小さくなるため, シード光の入射角も小さくする必要がある。また, Fig. 6 に 示すスペクトルでは，シード光波長 $1070 \mathrm{~nm}$ で凹面鏡の中 心近くを反射させているため, 短波長のシード光は一部分

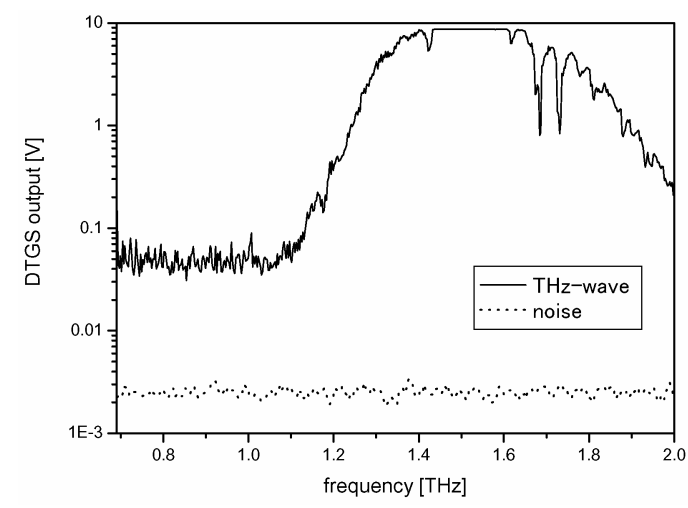

Fig. 6. THz-wave spectrum of the is-TPG.

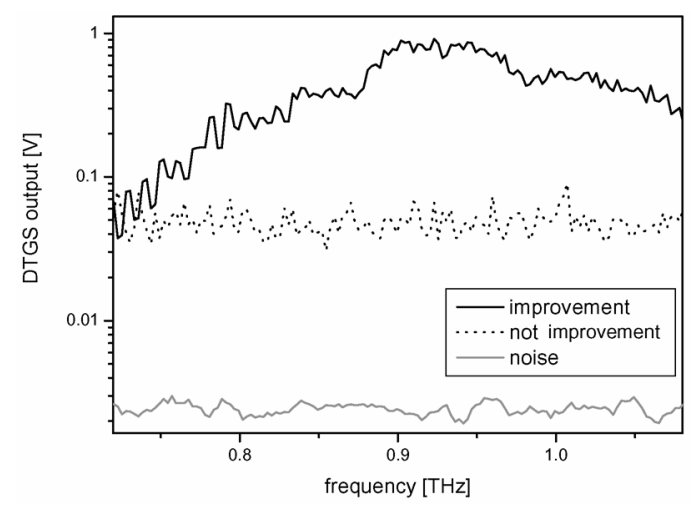

Fig. 7. THz-wave spectrum at low frequency.

が反射せず，パワーがロスしていると考えられる。しかし， この凹面鏡は, 短波長のシード光が中心で反射する位置に 置くと, ポンプ光の光路を遮ってしまうため, ポンプ光に 触れない範囲で，できるだけシード光の大部分を反射でき る位置に調整する必要がある。本研究で行うガスセンシン グには, 主に $1 \mathrm{THz}$ 以下の低周波帯を用いる。そのため, 低周波域において出力を向上させる必要がある。ここで, $1.5 \mathrm{THz}$ 付近の高周波域では, 位相整合角が多少正確に合っ ていなくても, THz 波は発生する。しかし，1 THz 以下の低 周波域では，位相整合角が厳密に合っていないと $\mathrm{THz}$ 波は 発生しない。Fig. 7 に低周波域での出力増強を目的としてシ ード光の調整を行った結果を示す。この結果から, 低周波 域での出力低下を従来よりも抑えることができた。また， 1 $\mathrm{THz}$ 付近以上で従来の光源に比べ, 出力が低下したが, CO ガスセンシング用として高周波域は用いないため, 今回は 低周波域のみに注目した。また, 大気空等の測定には $1 \mathrm{THz}$ 以上も用いるため, その際はその帯域に合わせて調整を行 うこととする。さらに, シード光波長 $1068 \mathrm{~nm}$ のときの波 長測定結果を Fig. 8 に示す。この帯域においても, シード光 の波長を変化させることで, 発生する $\mathrm{THz}$ 波の波長が変化 しており, 波長可変性を有することが確認でき, 実測值は 理論值と良い一致を示している。

次に, 減圧下の水蒸気を分光測定することで線幅の測定 を試みた。50 cm のガスセルを用い，0.09 Torr に減圧した。 


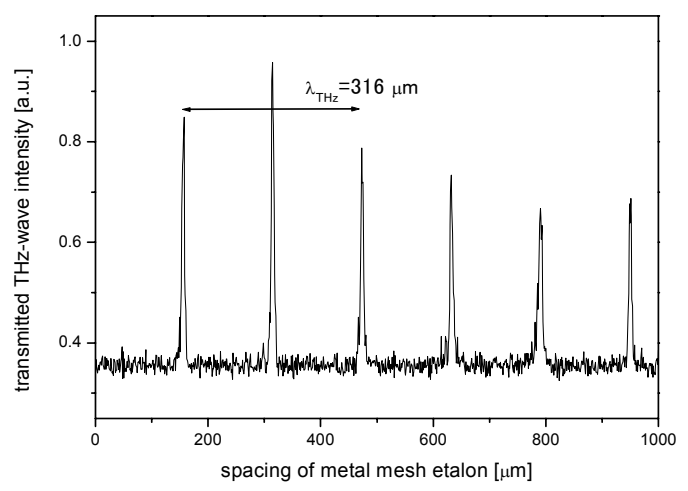

Fig. 8. $\mathrm{THz}$ wavelength measured with a scanning Fabry-Perot etalon at low frequency.

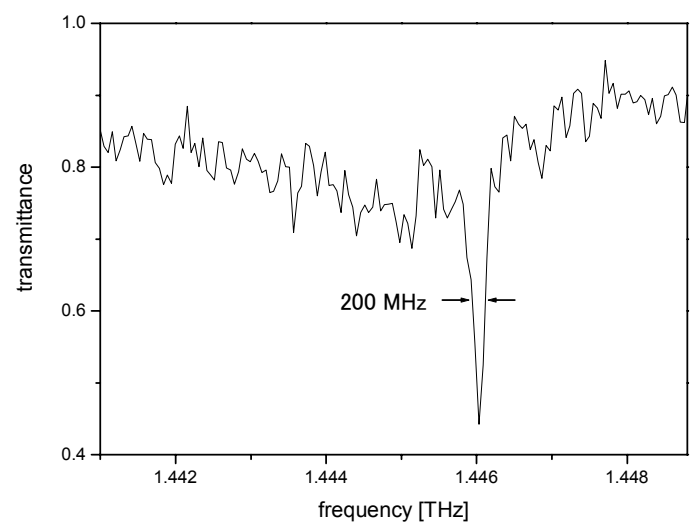

Fig. 9. Example of the absorption spectrum measurement of low pressure water vapor.

本測定では注入光波長を $0.2 \mathrm{pm}$ の間隔でスキャンしてい る。これは $\mathrm{THz}$ 波の周波数に換算すると, 約 $60 \mathrm{MHz}$ のス テップとなる。Fig. 9 に吸収スペクトルを示す。1.446 THz 付近の吸収線に対し約 $200 \mathrm{MHz}$ の分解能が得られている。

\section{5. is-TPG によるガスセンシング}

〈5·1〉 建材反射分光 実際の火災現場においては, $\mathrm{THz}$ 波を火災場所に出射させ，反射 $\mathrm{THz}$ 波を検出して，ガ スセンシングを行うことが想定される。そこで $\mathrm{N}_{2} \mathrm{O}$ ガスを 充填したガスセルを用い，一般的な建築物で用いられてい る金属系サイディングにより $\mathrm{THz}$ 波を反射させ，建材の反 射特性とガスの吸収スペクトルが混在する状況下でガスの 検知を行った。

実験系を Fig. 10 に示す。is-TPG から出射された THz 波は ワイヤーグリッドを透過し， $\mathrm{N}_{2} \mathrm{O}$ が封入されたガスセルに 入射する。ガスセル終端から出た THz 波は，建材で反射し て, もう一度ガスセルに入射する。その後ガスセルから出 射された THz 波はワイヤーグリッドで反射され，THz 波用 レンズを介し，シリコンボロメーターで受光した。本実験 では, ガスセル長は $50 \mathrm{~cm}$ とし, is-TPG からガスセルまで の距離は約 $10 \mathrm{~cm}$ である。 $\mathrm{N}_{2} \mathrm{O}$ ガスはガスセルを真空に引 き, 大気圧に到達するまで封入した。また, 大気密中の $\mathrm{CO}$ ガス検出のためには $0.8 \sim 0.9 \mathrm{THz}$ の領域が望ましいが，Fig.

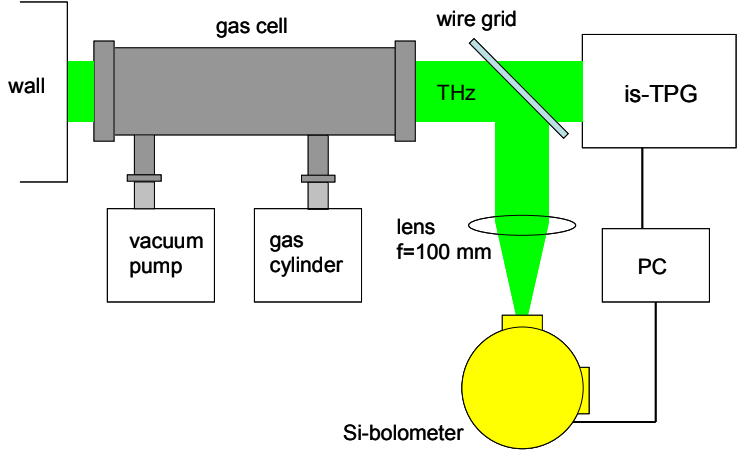

Fig. 10. Experimental setup for reflectance spectroscopy by the architectural material.

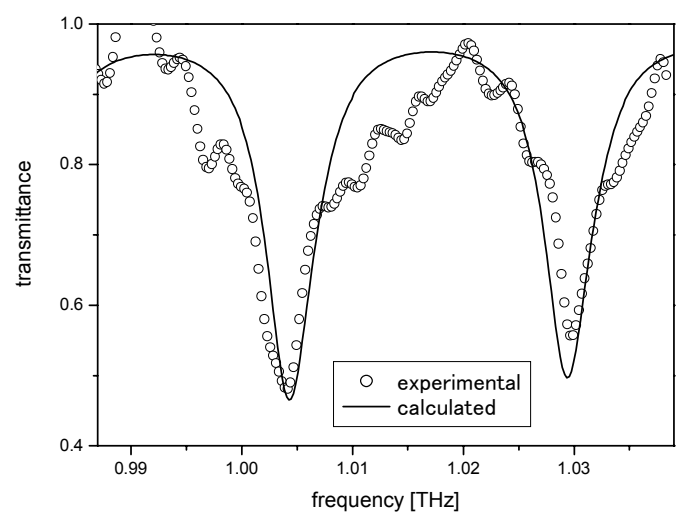

Fig. 11. Absorption spectrum of $\mathrm{N}_{2} \mathrm{O}$ by reflection of the architectural material.

10 で示した当該実験系では THz 波がワイヤーグリッドを 2 度通過する事から検出信号強度が $1 / 4$ に減衰寸るため, 当該 波長域で信号対雑音比 $20 \mathrm{~dB}$ を確保する事が難しかった。そ こで, 信号対雑音比 $20 \mathrm{~dB}$ を確保でき, かつ, $\mathrm{N}_{2} \mathrm{O}$ ガスの分 子回転運動に起因する吸収が存在する $1 \mathrm{THz}$ 近傍での測定 を行った。ただし, Fig. 2 に示したように $\mathrm{N}_{2} \mathrm{O}$ ガスの吸収度 は高周波側で減衰し， $0.8 \mathrm{THz}$ 近傍に比べて $1 \mathrm{THz}$ 近傍にお ける吸収度は低いため, 高濃度での実験を行っている。本 実験条件での $\mathrm{N}_{2} \mathrm{O}$ ガスによる透過率の変化は約 $50 \%$ であ り,これは Fig. 1 で示した計算における CO 濃度 $0.1 \% \sim 1.0 \%$ の領域に相当寸る。尚, 測定周波数領域において, 金属系 サイディングは比較的平坦な反射特性を有している。結果 をFig. 11 に示す。 $1.004 \mathrm{THz}$ 付近, $1.030 \mathrm{THz}$ における吸収 を確認することができた。実験により得られた吸収線幅は 約 $7 \mathrm{GHz}$ であり, 数值計算との良い一致が得られた。また, 高周波になるにつれて透過率が増加する特徵も確認するこ とができた。また，透過率が高い空の領域では，ガスセル の空材による干渉が起きていると考えられる。これは, 空 に角度をつけたウェッジ加工やブリュースター角で取り付 けることで干渉を取り除くことができると考えられる。建 材からの反射波スペクトルにてサンプルガスの吸収線を観 測できたことにより，THz 帯における遠隔分光センシング の実現可能性を実験的に示したと言える。 


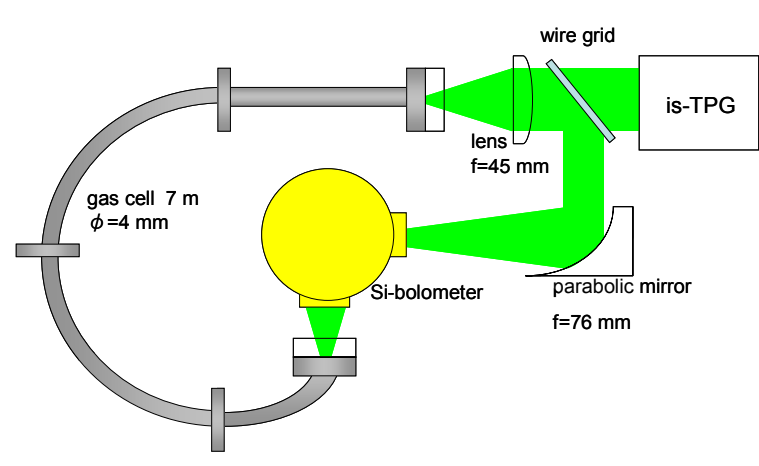

Fig. 12. Experimental setup for long-range propagation of the THz-wave.

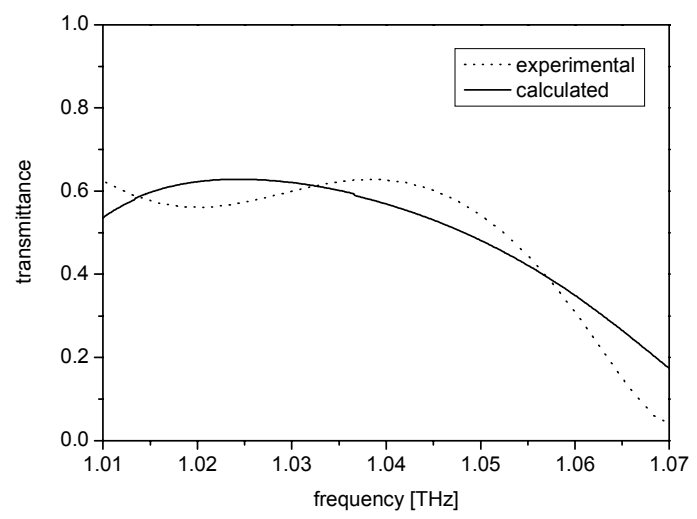

Fig. 13. Absorption spectrum of atmosphere. The THz-wave propagate atmosphere by 7 meter.

〈5·2〉大気空減衰率測定 本項では, $\mathrm{THz}$ 帯におけ る大気空の減衰率を実験的に求める。先に述べたように, 現行のシミュレーターでは水蒸気の圧力広がり係数に正確 な值を使用していないため, 実際のガスセンシングの使用 状況下を想定した， $\mathrm{THz}$ 波の長距離伝搬シミュレーション を信頼することはできない。そこで，実際に THz 波を長距 離伝搬させ, 大気空の減衰率を実験的に求める必要がある。 大気空測定の $\mathrm{THz}$ 波長距離伝搬は, $\mathrm{THz}$ 波光源の出力が高 く, 線幅もある程度細くなければならない。本研究で構築 した is-TPG はこの条件を満たしており，最適な光源の一つ であると言える。また, 過去に $\mathrm{THz}$ 帯での大気空長距離伝 搬測定の例は無く, 非常に重要な研究項目の一つである。

$\mathrm{THz}$ 波の SN 比と大気による減衰を考慮し, 初期段階の長距 離伝搬測定として, $7 \mathrm{~m}$ の伝搬測定を行った。実験系を Fig. 12 に示す。光源部で発生された $\mathrm{THz}$ 波を, 出力摇らぎをキ ヤンセルするためワイヤーグリッドで 2 成分に分割し, 透 過成分はレンズで集光し長さ $7 \mathrm{~m}$, 内径約 $4 \mathrm{~mm}$ のステンレ ス製ガスセルに入射し, セル内を透過した $\mathrm{THz}$ 波を $\mathrm{Si}$ ボロ メーター検出器で受光した。反射成分は放物面鏡を介し, もう一方の検出空で受光した。光源からガスセルまでの距 離は約 $10 \mathrm{~cm}$ である。また，大気空の測定は，真空状態と 大気状態の透過率の差を比べるため, ガスセルには真空排 気ポートが備えられている。
本実験は比較的出力が高く, かつ大気葖が存在する $1 \mathrm{THz}$ 付近で行った。また, シード光波長は $0.01 \mathrm{~nm}$ の間隔でスキ ヤンした。これは THz 波の周波数に換算すると約 $3 \mathrm{GHz}$ の ステップとなる。結果を Fig. 13 に示す。

この結果から，実験值と数值計算との誤差が $10 \%$ 以内で あることを確認した。数值計算の正確性が疑問視されてい た THz 波帯においても，その計算結果が実用に耐え得るも のであることを証明できた。即ち, 数值計算で求められた $60 \mathrm{~m}$ 伝播時の大気空による減衰は, Fig. 1 に示した值と同程 度であり, ガスセンシングにおいて本質的な問題とはなら ず，大気伝播損失は大きく見積もって $3 \mathrm{~dB}$ と想定すれば良 w。

一方，10 m の空間領域に死亡に至る危険性のある濃度 $0.1 \%$ CO ガスが充満している状況下では, 透過強度に大 気空に対して $15 \%$ 差が生じる。CO ガス充満領域の行路 長が半分になれば, 大気空に対する透過強度の差も半分と なる。部屋のサイズとしては最小 $3 \mathrm{~m}$ 程度を想定すれば良 く, 死亡の危険性のあるガス検出のためには, 信号対雑音 比として $30 \mathrm{~dB}$ を確保すれば十分である。また, 建築材から の反射として，金属系サイディング以外を想定しても反射 損失は最大で $20 \mathrm{~dB}$ 程度である。検出感度を低減させる要因 として, 煙霧による散乱等も想定されるが，これは今後実 験的に検討すべき課題である。現状としての見積りとして, 信号対雑音比 $60 \mathrm{~dB}$ を確保すれば確実に実用に耐え得るも のとなる。Si ボロメーターを検出器とした現行のシステム では, 当該周波数領域における信号対雑音比 $20 \mathrm{~dB}$ 程度であ るが, 超伝導ミキサー等の高感度検出器の導入によって信 号対雑音比 $60 \mathrm{~dB}$ を達成する事は原理的に可能である。

\section{6. むすび}

本論文では, 狭線幅 $\mathrm{THz}$ 波光源を構築し, 火災現場にお ける有毒ガスのセンシング技術について述べた。大気圧下 でのガスセンシングに適用可能な狭線幅 $\mathrm{THz}$ 波光源である is-TPG を構築し, 約 $200 \mathrm{MHz}$ まで狭線化し, 本システムに 要求される $1 \mathrm{GHz}$ 以下という值を十分満たすことができた。 低周波域において位相整合角が正確に合うように注入光を 調整することにより，ガスセンシングに用いる $1 \mathrm{THz}$ 以下 の帯域で THz 波出力を増大させた。また, 実際の火災現場 を想定し, 建築材料からの反射波を用いて $\mathrm{N}_{2} \mathrm{O}$ を分光する ことで, THz 帯遠隔分光センシングの実現可能性を実験的 に示した。さらに, 本システムを実現させる上で重要であ る大気空領域での長距離伝搬測定を行い, 大気の減衰率を 実験的に取得し計算值と良く一致したため, 数值計算が実 用に耐え得る物であることが証明された。

尚, 本研究は NiCT 委託研究「ICT による安全・安心を実 現するためのテラヘルツ波技術の研究開発」によって支援 されている。

建材をご提供いただきました有限会社スペクトルデザイ ンの深澤亮一代表取締役に深く感謝申し上げます。

(平成 20 年 3 月 17 日受付, 平成 20 年 8 月 19 日再受付) 


\section{文献}

(1) P. R. Smith, D. H. Auston, and M. C. Nuss : "Subpicosecond photo-conducting dipole antennas", IEEE J. Quantum Electron., Vol.24, pp.255-260 (1988)

(2) P. Y. Han and X.-C. Zhang : "Coherent, broadband midinfrared terahertz beam sensors", Appl. Phys. Lett., Vol.73, pp.3049-3051 (1998)

( 3 ) D. M. Mittleman, R. H. Jacobsen, and M. C. Nuss : "T-ray imaging", IEEE J. Sel. Top. Quantum Electron., Vol.2, pp.679-691 (1996)

(4) R. A. Cheville, R. W. McGowan, and D. Grischkowsky : "Time resolved measurements which isolate the mechanisms responsible for terahertz glory scattering from dielectric spheres", Phys. Rev. Lett., Vol.80, pp.269-272 (1998)

(5) J. Allen : "Free Electron Lasers and Other Advanced Sources of Light (National Academy Press, Washington, DC, 1994), pp.24-31

(6) S. Komiyama : "Far-infrared emission from population-inverted hot-carrier system in p-Ge", Phys. Rev. Lett., Vol.48, pp.271-274 (1982)

( 7 ) E. B. Brown, K. A. McIntosh, K. B. Nichols, and C. L. Dennis : "Photomixing up to $3.8 \mathrm{THz}$ in low temperature-grown GaAs", Appl. Phys. Lett., Vol.66, pp.285-287 (1995)

(8) J. Faist, F. Capasso, D. L. Sivco, C. Sirtori, A. L. Hutchinson, and A. Y. Cho : "Quantum cascade laser", Science, Vol.264, pp.553-556 (1994)

(9) S. S. Sussman : "Tunable Light Scattering from Transverse Optical Modes in Lithium Niobate", Microwave Lab., Report, No.1851, Stanford University (1970)

(10) M. A. Piestrup, R N. Fleming, and R. H. Pantell : "Continuously tunable submillimeter wave source”, Appl. Phys. Lett., Vol.26, pp.418-421 (1975)

(11) K. Kawase, J. Shikata, and H. Ito : "Terahertz wave parametric source", J. Phys. D: Appl. Phys., Vol.35, pp.R1-R14 (2002)

(12) J. Shikata, K. Kawase, K. Karino, T. Taniuchi, and H. Ito : "Tunable terahertz-wave parametric oscillators using $\mathrm{LiNbO}_{3}$ and $\mathrm{MgO}: \mathrm{LiNbO}_{3}$ crystals", IEEE Trans. Microwave Theory Tech., Vol.48, pp.653-661 (2000)

(13) Y. R. Shen, The Principle of Nonlinear Optics, John Wiley, and Sons, New York (1984)

(14) K. Imai, K. Kawase, H. Minamide, and H. Ito : "Achromatically injection-seeded terahertz-wave parametric generator", Opt. Lett., Vol.27, pp.2173-2175 (2002)

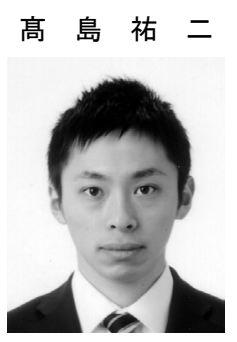

（非会員） 1983 年 8 月 25 日生。 2006 年 3 月名 古屋工業大学卒業。現在, 名古屋大学工学研究 科博士前期過程在学中。非線形光学効果を用い た $\mathrm{THz}$ 波発生に関する研究に従事。

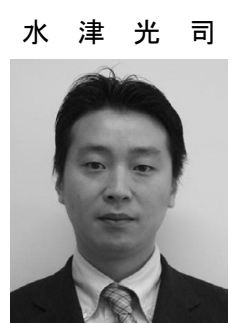

（非会員） 1974 年 1 月 24 日生。2001 年 3 月九 州大学大学院工学研究科応用物理学専攻博士 課程修了 (博士 (工学) )。2006 年 4 月より名古 屋大学大学院工学研究科助教。現在, テラヘル ツ光源・イメージングの研究に従事。

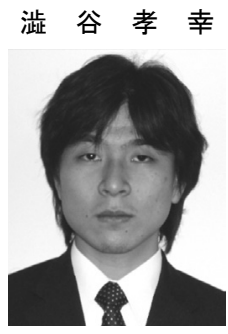

（非会員） 1980 年 6 月 30 日生。 2006 年 3 月東 京理科大学大学院工学研究科電気工学専攻修 了。2006 年 4 月より理化学研究所テラヘルツイ メージング研究チームテクニカルスタッフ, 名 古屋大学工学研究科博士後期課程在学中。現 在, テラヘルツ光源・イメージングの研究に従 事。

\section{大 谷 知 行}
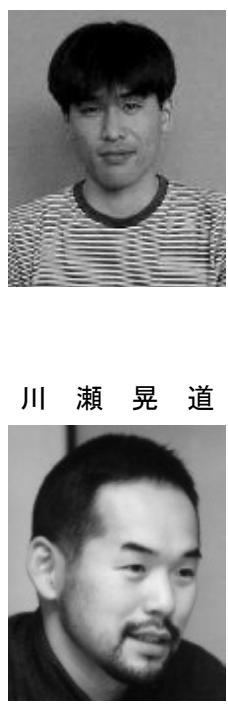

川瀬 晃 道
（正員） 1965 年 11 月 22 日生。1995 年 3 月東 京大学大学院理学系研究科天文学専攻博士課 程修了 (理学博士)。2005 年より理化学研究所 テラヘルツイメージング研究チームチームリ ーダー。現在, 超伝導テラヘルツ波検出器の開 発と応用に従事。
） 1966 年 9 月 14 日生。 1996 年 3 月東北 大学大学院工学研究科電子工学専攻博士課程 修了 (博士 (工学) )。2005 年 7 月名古屋大学工 学研究科教授。2007 年 4 月より名古屋大学エコ トピア科学研究所教授。現在, テラヘルツ光 源・イメージングの研究に従事。 